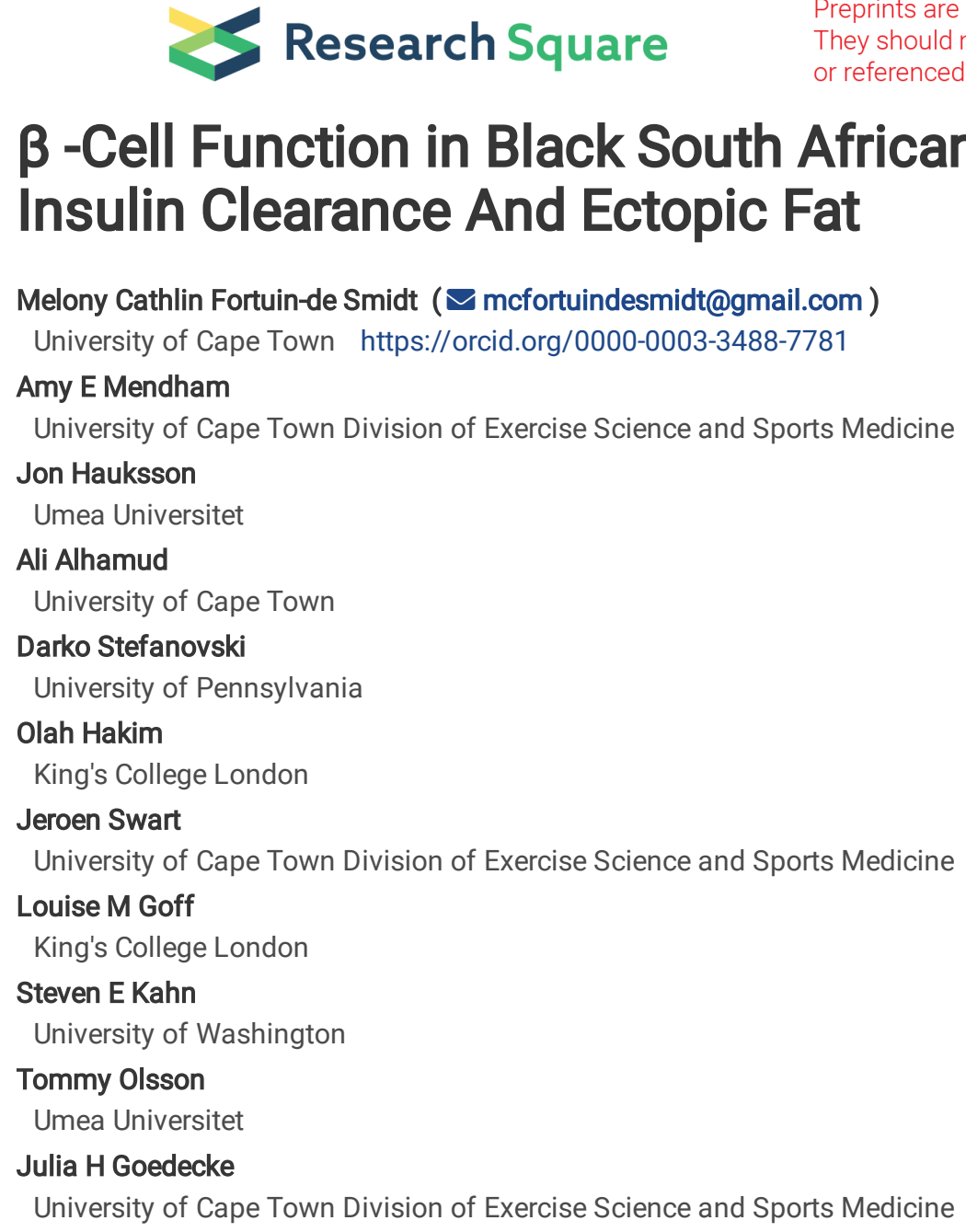

Melony Cathlin Fortuin-de Smidt ( $\square$ mcfortuindesmidt@gmail.com )

University of Cape Town https://orcid.org/0000-0003-3488-7781

Amy E Mendham

University of Cape Town Division of Exercise Science and Sports Medicine

Jon Hauksson

Umea Universitet

Ali Alhamud

University of Cape Town

Darko Stefanovski

University of Pennsylvania

Olah Hakim

King's College London

Jeroen Swart

University of Cape Town Division of Exercise Science and Sports Medicine

Louise M Goff

King's College London

Steven E Kahn

University of Washington

Tommy Olsson

Umea Universitet

Julia H Goedecke

University of Cape Town Division of Exercise Science and Sports Medicine

\title{
$\beta$-Cell Function in Black South African Women: Associations With Insulin Clearance And Ectopic Fat
}

\section{Research}

Keywords: $\beta$-cell function, hepatic insulin extraction, peripheral insulin clearance, insulin secretion, visceral fat, pancreatic fat, hepatic fat, skeletal muscle fat

Posted Date: June 17th, 2020

DOl: https://doi.org/10.21203/rs.3.rs-35455/v1

License: (9) This work is licensed under a Creative Commons Attribution 4.0 International License. Read Full License 


\section{Abstract}

Background: The role of ectopic fat, insulin secretion and clearance in the preservation of $\beta$-cell function in obese, black African women who typically present with hyperinsulinemia is not clear. We aim to examine the associations between disposition index ( $\mathrm{DI}$, a measure of $\beta$-cell function), insulin secretion and clearance and ectopic fat deposition.

Methods: This is a cross-sectional study of 43 obese (BMI $30-40 \mathrm{~kg} / \mathrm{m}^{2}$ ) black South African (women (age 20-35 years) without type 2 diabetes that measured the following: DI, insulin sensitivity ( $\mathrm{S}_{\mathrm{I}}$ ), acute insulin response (AIRg), insulin secretion rate (ISR), hepatic insulin extraction and peripheral insulin clearance (frequently-sampled intravenous glucose tolerance test); pancreatic and hepatic fat, visceral adipose tissue (VAT) and abdominal subcutaneous adipose tissue (SAT) volume (magnetic resonance imaging), intramyocellular (IMCL) and extramyocellular fat content (EMCL) (magnetic resonance spectroscopy). DI correlated positively with peripheral insulin clearance before ( $\beta$ $55.80, p=0.002$ ) and after adjusting for hepatic insulin extraction. Higher DI was associated with lower VAT, pancreatic fat and soleus fat, but VAT explained most of the variance in DI (32\%). Additionally, higher first phase ISR $(p=0.033)$ and lower hepatic insulin extraction $(p=0.022)$ associated with lower VAT, independent from $\mathrm{S}_{\mathrm{I}}$, rather than with ectopic fat.

Conclusion: Peripheral insulin clearance emerged as an important determinant of DI, independent from hepatic insulin extraction. However, VAT was the main determinant of a lower DI above ectopic fat depots. Importantly, VAT, but not ectopic fat, was associated with both lower insulin secretion and higher hepatic insulin extraction, independent from $S_{1}$, and may provide a novel explanation of these findings in obese black South African women.

\section{Background}

The acute insulin response (AIRg) relative to the prevailing level of insulin sensitivity $\left(\mathrm{S}_{\mathrm{I}}\right)$ described by the disposition index (DI), reflects $\beta$-cell function, which is a key component in the pathogenesis of type 2 diabetes (T2D) [1]. The primary events in the development of T2D may differ between black Africans and their white counterparts. Indeed, black Africans without T2D present with lower $\mathrm{S}_{\text {I }}$ and hyperinsulinaemia, characterised by greater fasting insulin and AIRg in comparison to white individuals [2]. In some cases the AIRg response is exaggerated for the level of $S_{1}[3]$, resulting in a higher DI. Determinants of $S_{1}$ in black African populations have been studied extensively but there is limited evidence on the determinants of hypersinsulinemia and its components, namely insulin secretion rate (ISR) and insulin clearance.

The relative contribution of first phase ISR and insulin clearance to a high AIRg, independent from $\mathrm{S}_{\mathrm{l}}$, is essential to our understanding of the pathogenesis of T2D in African populations. However, this has only been reported in African American children [4], with no studies in obese, black African adults without T2D. A lower hepatic insulin extraction is found in black African women [5] which contributes towards a high AlRg [4], but how it relates to DI is unknown. Although, peripheral insulin clearance has been measured in two studies that included African American adults $[5,6]$, the association with $\beta$-cell function measures was not assessed and needs further clarification.

An important link between alterations in DI and its components, may be ectopic fat accumulation in the visceral compartment (VAT), liver, skeletal muscle and pancreas. Few studies have assessed associations between measures of $\beta$-cell function and VAT [7-9] and ectopic fat deposition $[10,11]$ in African Americans, but no studies have been undertaken in an African cohort, which is required to determine if this phenotype is robust. Indeed, studies from Africa and the USA have consistently shown that black populations presents with lower ectopic fat accumulation compared to white populations $[10,12,13]$, together with hyperinsulinemia [2] and paradoxically a higher prevalence of T2D. Whether black African populations exhibit a greater sensitivity to ectopic fat accumulation or whether ectopic fat is not an important determinant of $\beta$-cell function and its components requires further elucidation. Accordingly, this study, aimed to evaluate the determinants of $\beta$ cell function, assessed by DI, focusing on hyperinsulinemia (insulin secretion, hepatic insulin extraction and peripheral insulin clearance) and its association with ectopic fat depots in obese black South African women.

\section{Methods}

\section{Research design}

This study was a cross-sectional analysis of baseline data obtained from a randomized controlled exercise intervention study, for which the study design and methods have been published previously [14] . Participants were recruited from low socio-economic areas in Cape Town, South Africa. Ethical permission was obtained from the University of Cape Town Human Research Ethics Committee. The trial was registered in the Pan African Clinical Trial Registry (PACTR201711002789113).

\section{Participants}


Obese (BMI 30-40 kg/m²), black African women that fulfilled the following inclusion criteria were enrolled: age 20-35 years, stable weight (<5 kg change in weight in the last 6 months), using injectable contraception (depot medroxyprogesterone acetate, $400 \mathrm{mg}$ ) for a minimum of 2 months prior to testing. Self-reported ancestry with both parents of isIXhosa descent. Participants were excluded if they had any known diseases (e.g. HIV, hypertension, diabetes), were pregnant, lactating or smoking. After written informed consent was obtained, patients were screened for inclusion.

\section{Body composition}

Anthropometry included weight, height, hip and waist circumferences measured using standardized methods. Whole body composition was measured by dual-energy X-ray absorptiometry (DXA; Discovery-W®, software version 12.7.3.7; Hologic, Bedford, MA) for the analyses of subtotal body (whole body minus head) fat mass and fat-free soft tissue mass, as well as trunk and leg mass (expressed as percent of sub-total body fat mass) [15].

\section{Ectopic and central fat quantification}

Pancreatic, hepatic and skeletal muscle (soleus, tibialis anterior) fat content, VAT and abdominal subcutaneous adipose tissue (aSAT) volumes were analysed using a 3 Tesla whole-body human magnetic resonance imaging scanner (MRI; MAGNETOM Skyra; Siemens Medical Solutions, Erlangen, Germany) using a two-point Dixon method as described previously [14]. Soleus and tibialis anterior intra-myocellular (IMCL) and extra-myocellular (EMCL) fat content were determined by magnetic resonance spectroscopy (MRS) using a point-resolved spectroscopy sequence with the following parameters: TR/TE $3000 / 33$ ms, bandwidth $2000 \mathrm{~Hz}, 80$ averages with voxel dimensions of $15 \times 15 \times 15 \mathrm{~mm}{ }^{3}$.

For the determination of hepatic, pancreatic and skeletal muscle fat, VAT and aSAT obtained by MRI, a fat fraction map was created, calculated as the fat signal over the sum of the water and fat signals. A region of interest (ROI) was drawn on 7 consecutive slices in the right lobe of the liver. In the soleus and tibialis anterior muscles, an ROI was drawn on 7 consecutive slices with a method adapted from Machann et al. [16]. Pancreatic fat was determined by drawing one circular $1 \mathrm{~cm}^{2} \mathrm{ROI}$ in the head, body and tail of the pancreas to calculate the average [17]. The methods for determining VATand aSAT volumes were previously published [18]. The above mentioned methods, to quantify hepatic [19], pancreatic [20] and skeletal muscle fat [21] and VAT and aSAT [22], have previously been reported to have high precision.

\section{Determination of $S_{\mid}$and $\beta$-cell function}

A frequently sampled intravenous tolerance test (FSIGT) was conducted after an overnight fast (10-12 h). Glucose (50\% dextrose, $11.4 \mathrm{~g} / \mathrm{m}^{2}$ body surface area) was infused at 0 min over a 60 s period. At 20 min, human insulin (0.02 unit/kg; NovoRapid, Novo Nordisk Limited, Cape Town, SA) was infused over $5 \mathrm{~min}$ at a constant rate. Blood samples were drawn for the determination of insulin, glucose and C-peptide.

\section{Biochemical analyses}

Fasting whole blood was collected and analysed for HbA1c using high-performance liquid chromatography (Meharini Diagnostics, Florence, Italy). Plasma glucose concentrations was measured using a colorimetric assay (Randox (Pty) Ltd, Gauteng, South Africa). Serum insulin and C-peptide concentrations were determined by an immunochemiluminometric assay (IMMULITE 1000 immunoassay system, Siemens Healthcare (Pty) Ltd, Midrand, South Africa).

\section{Mathematical modelling}

The minimal model of glucose kinetics was used to calculate $S_{l}, A_{\mathrm{R}}$ and glucose effectiveness [23]. The ISR was determined by C-peptide deconvolution using a 2-compartmental model with standard kinetic parameters for obese individuals [24]. The incremental area-under curve (AUC), above baseline, for ISR, glucose, insulin and C-peptide were calculated using the trapezoidal rule for the first 10 minutes and the entire 240 min of the FSIGT, and are referred to as the first phase AUC (ISR first phase) and the total AUC (ISR total $\left._{\text {, }}\right)$, respectively.

Hepatic and peripheral insulin clearance (CLp) were calculated using a method previously described by Polidori et al.[6]. Hepatic insulin clearance were described using both linear and saturable kinetics. The linear model estimated a single parameter for hepatic insulin clearance $\left(\mathrm{FE}_{\mathrm{L}}\right)$ while the saturable model estimated two parameters (Vmax and $\mathrm{Km}$ ). The linear model described hepatic insulin clearance well (fractional standard deviation $<5 \%$ ) in $91 \%$ (39/43) of participants. In addition, the linear model described the plasma insulin values with a mean normalized root square error (NMRSE) \pm SD of $8.3 \pm 2.14 \%$. The parameters of the models were estimated using WinSAAM [25].

\section{Statistical analysis}

Data were analysed using STATA 12.0 (College Station, TX, USA). Data analysis included those that completed a FSIGT ( $\mathrm{n}=43$ ). The cohort

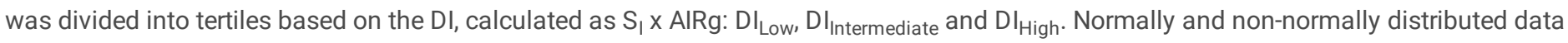


were expressed as mean \pm standard deviation (SD) and median (25-75 th percentile), respectively. Differences between DI tertiles was determined using one-way ANOVA with a Bonferroni post hoc test or Kruskal Wallis test with the Dunn post hoc test for normally and nonnormally distributed data, respectively. Correlations were conducted using Pearson (normally distributed variables) and Spearman (nonnormally distributed variables). Linear regression was performed with the transformed variables to determine the association between $\mathrm{DI}$ components and central fat depots, adjusted for $S_{1}$, where applicable.

\section{Results}

\section{Subject Characteristics}

The cohort had a median age of 23 (IQR 21-27) years and were obese (BMI $33.2 \pm 2.8 \mathrm{~kg} / \mathrm{m}^{2}$ ). Participant characteristics by DI tertile, as an estimate of $\beta$-cell function, are displayed in Table 1. The group with the highest DI, were the most insulin sensitive (post hoc $\mathrm{p}=0.001)$ and had the highest glucose effectiveness (post hoc $\mathrm{p}<0.001$ ) compared to the group with the lowest DI. AIRg and ISR $\mathrm{first}_{\text {phase }}$ showed a gradual decline across DI tertiles (post hoc $\mathrm{p}=0.060$ and $\mathrm{p}=0.071$, respectively). In addition the group with the highest DI had the highest CLp (post hoc $\mathrm{p}=0.001$ ) and lowest $\mathrm{FE}_{\mathrm{L}}$ (post hoc $\mathrm{p}=0.049$ ). compared to those in the lowest DI tertile. Further, the highest $\mathrm{DI}$ had the lowest pancreatic and hepatic fat, and the lowest VAT and VAT-aSAT ratio, compared to those with the lowest DI.

\section{Relationship of DI with its components}

DI was positively associated with both its immediate components ( $S_{\text {: }}$ rho $0.459, p=0.020 ;$ AIRg: rho 0.372, $\left.p=0.014\right)$ ) and ISR first phase $($ rho $0.350, p=0.0213)$. Further, in univariate analysis, $\mathrm{DI}$ was positively associated with CLp and inversely with $\mathrm{FE}_{\mathrm{L}}$ which explained $23.4 \%$ and $16.8 \%$ of the variance in $\mathrm{DI}$, respectively (Table 2 ). However, when both CLp and FE $\mathrm{E}_{\mathrm{L}}$ were placed in the model only CLp remained a significant positive determinant of DI. $S_{\text {I }}$ tended to be positively associated with $\mathrm{FE}_{\mathrm{L}}(\mathrm{p}=0.065)$, but was not associatedwith CLp, in the univariate model (Table 2). The association between $S_{\mid}$and $F E_{L}$ became significant when adjusted for $C L p(p=0.038)$. AIRg was associated with CLp in the univariate analysis but after adjusting for $\mathrm{FE}_{\mathrm{L}}$ and $\mathrm{S}_{\mathrm{I}}$ this association was diminished (Table 2). In addition, we used linear regression models to determine the relative contributions of $\mathrm{FE}_{\mathrm{L}}$ and $\mathrm{ISR}_{\mathrm{first}}$ phase to $\mathrm{AIRg}$, without and with adjustment for $\mathrm{S}_{\mathrm{I}}(\mathrm{Table} 3)$. In the univariate models, $I_{S R}$ first phase and $F_{L}$ explained $81.9 \%$ and $57.6 \%$, of the variance in AIRg, respectively. $S_{\text {I }}$ explained $32 \%$ of the variance in AIRg (data not shown). In the multivariate model, $\mathrm{FE}_{\mathrm{L}}$ and $\mathrm{ISR}_{\text {first phase }}$ were independently associated with AIRg, adjusted for $\mathrm{S}_{\mathrm{I}}$.

\section{DI and its components - associations with ectopic fat and body fat distribution}

The associations between DI and ectopic fat depots, are shown in Figure 1. DI was inversely correlated with pancreatic fat, total soleus fat and both soleus IMCL and EMCL. Moreover, DI was negatively associated with VAT and the VAT-aSAT ratio $(\beta-167.4, p<0.001)$. DI was not associated with fat mass (\%), tibialis anterior fat, leg fat mass or aSAT (data not shown). In univariate analysis, VAT explained $32 \%$ of the variance in DI, while soleus IMCL explained 18.7\%, soleus EMCL 10.9\% and pancreatic fat 12\%. Adjusting for age and fat mass (\%) in multivariable models did not alter the models (data not shown). We explored the associations between DI and ectopic fat, independent of VAT and found that the associations of DI with pancreatic fat, hepatic fat, soleus fat and soleus IMCL were ameliorated to non-significance ( $p>0.05$ ) (data not shown). Instead, VAT remained a significant determinant of DI independent of any of the ectopic fat depots (data not shown).

The components of DI ( $S_{l}, A I R g$, ISR first phase, $F_{L}$ and CLp) were not associated with fat mass (\%) or ectopic fat sites ( $p>0.05$ ) (data not shown). Rather, significant associations were found between the components of DI and central fat measures (Table 4). A lower $\mathrm{S}_{\mathrm{I}}$ was associated with higher VAT but not aSAT, while higher AIRg was associated with higher aSAT and lower VAT-aSAT. When adjusting for $\mathrm{S}_{\mathrm{l}}$, a higher AIRg was associated with only a lower VAT and VAT-aSAT. Only after adjusting for $\mathrm{S}_{\mathrm{I}}$, an inverse association emerged between ISR $\mathrm{first}_{\text {phase }}$ and VAT. We further showed that $\mathrm{FE}_{\mathrm{L}}$ was positively associated with VAT only after adjusting for $\mathrm{S}_{\mathrm{I}}$. CLp was not associated with any central fat depots (data not shown). In terms of peripheral fat deposition, $S_{\text {I }}$ was positively associated with leg fat mass (rho 0.411, p=0.007), whereas both AIRg and $\mathrm{ISR}_{\text {first phase }}$ were negatively associated with leg fat mass, but not when adjusting for $\mathrm{S}_{\mathrm{I}}$. Further $\mathrm{FE}_{\mathrm{L}}$ and $\mathrm{CLp}_{\mathrm{p}}$ were not associated with leg fat mass, without or with adjustment for $S_{I}$ (data not shown).

Lastly, we explored the associations between VAT and ectopic fat depots (Table 5). VAT was positively associated with pancreatic fat (rho 0.417, $p=0.007$ ) and soleus IMCL (rho 0.403, $p=0.014$ ), but not soleus EMCL ( $p=0.474$ ) and showed a positive trend with hepatic fat (rho 0.300, $\mathrm{p}=0.060$ ). Moreover, pancreatic fat was positively associated with hepatic fat (rho 0.540, $p<0.001$ ).

\section{Discussion}


The determinants of $\beta$-cell function, a critical factor in the pathogenesis of T2D, are incompletely understood, especially in black African populations who present with a phenotype of low $S_{\text {I, }}$ hyperinsulinemia and low ectopic fat deposition. Our study extend existing evidence by demonstrating that DI was positively associated with CLp. Notably, the major determinant of AIRg was ISR first phase, above insulin clearance. VAT emerged as the strongest determinant of DI, above and independent of pancreatic fat and soleus fat. Additionally, we showed that a lower VAT also associated with a higher $\mathrm{ISR}_{\text {first phase }}$ and lower $\mathrm{FE}_{\mathrm{L}}$. Thus, our findings suggest that VAT is a more important determinant of a lower DI than ectopic fat in this cohort, not only through its association with a lower $\mathrm{S}_{\text {, }}$, but also through its relation with the AIRg downstream components, ISR and $\mathrm{FE}_{\mathrm{L}}$.

Our study, not only distinguishes between $\mathrm{FE}_{\mathrm{L}}$ and CLp, which has only been done in a few studies in adults without T2D [5,6,26], but we also demonstrated for the first time a positive association between DI and CLp. The reason for this relationship is unclear. Nevertheless, considering DI is based on the product of $S_{I}$ and AIRg, we can postulate two scenarios. Firstly, a higher DI may be due to a hyperinsulinemia relative to the the level of $S_{1}$. However, hyperinsulinemia has been associated with lower insulin clearance in both adipose tissue [27] and muscle [28], due to reduced affinity of insulin receptors at these sites, and is therefore an unlikely explanation for our finding of a higher CLp relative to higher DI. Secondly, a higher DI could be due to a greater $S_{\mid}$in relation to the level of AIRg. In this scenario, a higher CLp may be due to enhanced binding of insulin to insulin receptors in peripheral tissues. Although a positive association has been demonstrated between $S_{1}$ and hepatic insulin clearance [29], no association between insulin internalization, a measure of insulin clearance, and S, was observed in rat adipocytes [27], whereas the association between $S_{1}$ and insulin clearance in muscle is unknown. However, in support of the second scenario, we showed that those with the highest DI and CLp were also more insulin sensitive, but only exhibited a slightly higher AIRg compared to those with lower DI and CLp. Nevertheless, CLp was not associated with $\mathrm{S}_{\mathrm{I}}$ in our study, but rather with the insulin secretory component. Further, we may also consider that the observed association between $\mathrm{DI}$ and CLp is in compensation for a lower $\mathrm{FE}_{\mathrm{L}}$, but this association remained independent of $\mathrm{FE}_{\mathrm{L}}$. We also evaluated the associations of CLp with ectopic fat deposition as possible explanation for the association with DI, but found that

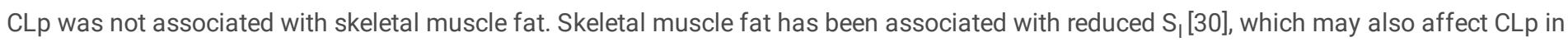
the muscle. Further study is justified to evaluate the relationship between CLp and $\mathrm{S}_{\mathrm{I}}$ in the muscle, considering that the muscle is only secondary to the kidney in the proportion of insulin cleared in the periphery [31]. Of note, CLp in our study is much higher compared to another study conducted in black American women [5]. However, the acute insulin response in our cohort was twice as high as that observed in Piccinini et al, and may contribute to this discrepancy.

Preservation of $\beta$-cell function is critical for delaying the onset of T2D. We, therefore, investigated, firstly, whether ectopic fat accumulation may explain the variance in DI and secondly, we assessed the associations of ectopic fat with the components of DI. Our study demonstrated that a higher DI was associated with a lower pancreatic and soleus fat and a tendency towards a lower hepatic fat, but these associations were not independent from VAT. A similar observation was found in overweight African American and Hispanic adolescents (13 to 25 years old) without T2D [32]. In contrast a positive association between DI and pancreatic fat, adjusted for BMI and VAT, was shown in black African American women [11]. However, this study included participants with and without T2D, which may explain the incongruent findings. Our study extends the literature by showing that pancreatic fat was not associated with $\mathrm{ISR}_{\mathrm{first}}$ phase or with $\mathrm{FE}_{\mathrm{L}}$ in black Africans. Notably, a positive association was found between pancreatic fat and VAT in our study. Our findings therefore suggest that pancreatic fat may only be a marker of VAT accumulation and is not detrimental to $\beta$-cell function in this cohort.

The ability to maintain $\beta$-cell function and prevent deteriorating glucose tolerance depends on the balance between AIRg and $\mathrm{S}_{\mathrm{I}}[1]$. However, there is no consensus on the mechanism of maintaining a higher AIRg, which is frequently observed in black African populations [2,3]. Some studies reported that a lower hepatic insulin clearance alone is responsible for a higher AIRg [33,34], while others showed that both lower hepatic insulin clearance and higher ISR contribute towards a higher AIRg [3,5]. Notably, AIRg may be out of proportion for the level of $\mathrm{S}_{\mathrm{I}}$, and to assess the relative contribution of $\mathrm{ISR}_{\text {first phase }}$ and insulin clearance to AIRg in this context, we need to adjust for $\mathrm{S}_{\mathrm{I}}$. Accordingly, a lower $\mathrm{FE}_{\mathrm{L}}$

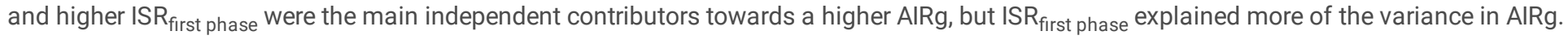
Lowering hepatic insulin clearance is an important compensatory mechanism to reduce the strain on the pancreatic $\beta$-cells, which has been shown in canines [35]. However, we have shown that a higher ISR associates with AIRg, independently of lower $F_{L}$ and $S_{l}$, suggesting that despite a lower $F E_{L}$, pancreatic $\beta$-cells may continue to secrete insulin at a higher rate, which may be detrimental to the longevity of the $\beta$-cell in this cohort.

The current study further examined the associations between the components of AIRg and ectopic fat. Previously, reduced hepatic insulin clearance and increased insulin secretion, have been associated with hepatic fat accumulation [36]. An association between fasting hepatic insulin clearance and hepatic fat was studied in African American women [13], but the association between stimulated hepatic insulin clearance, which is a more physiological response, and hepatic fat has not been previously investigated in black African populations without T2D . We showed that hepatic fat was not associated with $\mathrm{FE}_{\mathrm{L}}$ and ISR in obese black South African women. Therefore, in black African populations, hepatic fat may not be an important determinant of hepatic insulin clearance and insulin secretion prior to T2D, and also not in

Page 5/14 
those with early T2D [37]. Instead, we found that a lower ISR $_{\text {first phase }}$ and higher FE $_{\mathrm{L}}$ was associated with higher VAT. This highlights a novel mechanism to explain the association between AIRg and VAT since to the best of our knowledge, no previous study has evaluated the effect of central fat depots on $\mathrm{FE}_{\mathrm{L}}$. In addition, evidence on the associations between central fat depots and ISR, determined by $\mathrm{C}$-peptide deconvolution

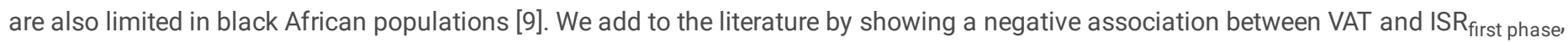
independent of $S_{\text {, }}$ in premenopausal black South African women. Interestingly, black African women have lower VAT compared to other ethnicities [2,3], but they have a greater propensity to increase VAT over time, with the greatest increase occurring in the 20-29-year age group [38]. However, further studies are needed to confirm the effect of VAT on ISR in this cohort.

We also assessed the association between $S_{\mid}$and ectopic fat and found no association between $S_{\mid}$and skeletal muscle or hepatic fat. These findings suggest that these ectopic fat depots are not important contributors to $S_{\text {I }}$ in our study. However, we should consider that we measured whole body $S_{\mid}$, which could have diluted the associations with hepatic and soleus fat. Indeed, a small South African study found that in black South African women, hepatic fat was associated with hepatic $S_{\mid}$but not peripheral $S_{\mid}[12]$. Furthermore, total soleus fat and soleus IMCL were associated with peripheral $S_{I}$, but not hepatic $S_{I}[12]$. Nevertheless, lower $S_{\text {I }}$ was associated with higher VAT which may contribute to the observed inverse association between DI and VAT in this cohort.

A major strength of this study is that ISR and both hepatic and peripheral clearance were determined using mathematical modelling, which has never been done before in an African cohort. Further we assessed pancreatic, hepatic and skeletal muscle ectopic fat depots, as well as VAT and aSAT volumes using MRI. However, limitations of this study were that we did not determine glucose tolerance, and we did not distinguish between hepatic and peripheral $S_{\text {| }}$. In addition, these findings are applicable to premenopausal, obese black South African women and may not be extrapolated to men or other races.

In conclusion, an original finding from this study was that DI was associated with CLp, independent from $F E_{L}$. Further, while both $F E_{L}$ and

$\mathrm{ISR}_{\text {first phase }}$ independently contributed towards hyperinsulinemia, ISR first phase was more important. Ectopic fat was not an important independent determinant of DI and its components. Rather, a key finding was that higher VAT was the principal determinant of a lower DI, above other ectopic fat depots. Additionally, the associations of higher VAT on the downstream components of DI, a lower ISR first phase $_{\text {and }}$ higher $\mathrm{FE}_{\mathrm{L}}$ may contribute to lower DI prior to T2D onset but requires further elucidation. Accordingly, the prevention of VAT accumulation, especially in young black African women should be an important target for $\beta$-cell preservation.

\section{Abbreviations}

AIRg: Acute insulin response to glucose; aSAT: Abdominal subcutaneous adipose tissue; AUC: Area under curve; BMI: Body mass index; CLp: Peripheral insulin clearance; DI: Disposition index; DXA: Dual-energy X-ray absorptiometry; EMCL: Extramyocellular lipid; FE insulin extraction; FSIGT: Frequently sampled intravenous glucose tolerance test - insulin modified; IMCL: Intramyocellular lipid; ISR: Insulin

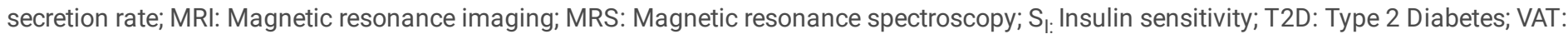
Visceral adipose tissue

\section{Declarations}

\section{Ethics approval and consent to participate}

Ethical approval was obtained from the University of Cape Town Human Research Ethics Committee (reference number 799/2015). This study formed part of a randomized controlled trial that was registered in the Pan African Clinical Trial Registry (PACTR201711002789113). All study participants provided written informed consent to participate in the study. The study was conducted in accordance to ethical principles outlined in the Declaration of Helsinki.

\section{Consent for publication}

All the study participants provided informed consent to participate in the study.

\section{Competing interest}

All the authors have nothing relevant to disclose.

\section{Acknowledgments}

The authors thank Nandipha Sinyanya, Ntombekhaya Zoneleni, Keitumetse Smouse and Hendriena Victor for their valuable contribution towards the study. 
This study was funded by the National Research Foundation of South Africa (NRF), Competitive Programme for Rated Researchers (Grant no: 93577), the NRF/ STINT Sweden/South Africa Research Collaboration Programme (UID: 106784), the South African Medical Research Council (SAMRC). MF is a recipient of SAMRC, through its Division of Research Capacity Development, Clinician Researcher Development PhD Scholarship Programme. The content hereof is the sole responsibility of the authors and does not necessarily represent the official views of the SAMRC. SK is supported in part by the United States Department of Veterans Affairs.

\section{Availability of data and materials}

The data and materials used to support the findings in this study is available from the corresponding author upon a reasonable request.

\section{Author contributions}

AM, JG, TO conceived and designed the study. MF, AM, JG, JS performed study procedures. MF, AA, JH, OH performed MRI fat quantification. MF, DS performed mathematical modelling. MF prepared figures and drafted the manuscript. MF, AM, JG were involved in data analysis. MF, $A M, J G, T O, J S, S K, J H, D S, L G, A A, O H$ read and edited the manuscript and approved the final version. MF, AM and JG are the guarantors of this work and, as such, has full access to all the data in the study and take responsibility for the integrity of the data and the accuracy of the data analysis.

\section{Author details}

${ }^{1}$ Division of Exercise Science and Sports Medicine, Department of Human Biology, University of Cape Town, Cape Town, South Africa, ${ }^{2}$ NonCommunicable Diseases Research Unit, South African Medical Council, Tygerberg, South Africa, ${ }^{3}$ Department of Radiation Sciences, Radiation Physics and Biomedical Engineering, Umeå University, Umeå, Sweden,

${ }^{4}$ Department of Human Biology, MRC/UCT Medical Imaging Research Unit, University of Cape Town, Cape Town, South Africa, ${ }^{5}$ Department of Clinical Studies, New Bolton Center, University of Pennsylvania, School of Veterinary Medicine, Kennett Square, Pennsylvania, USA,

${ }^{6}$ Department of Diabetes, School of Life Course Sciences, Faculty of Life Sciences \& Medicine, King's College London, London, UK, ${ }^{7}$ Division of Metabolism, Endocrinology and Nutrition, Department of Medicine, Veterans Affairs Puget Sound Health Care System, University of Washington, Seattle, WA, USA, ${ }^{8}$ Department of Public Health and Clinical Medicine, Umeå University, Umeå, Sweden

\section{References}

1. Kahn SE, Prigeon RL, McCulloch DK, Boyko EJ, Bergman RN, Schwartz MW, et al. Quantification of the relationship between insulin sensitivity and beta-cell function in human subjects. Evidence for a hyperbolic function. Diabetes. 1993;42:1663-72.

2. Goedecke JH, Dave JA, Faulenbach MV, Utzschneider KM, Lambert EV, West S, et al. Insulin response in relation to insulin sensitivity: an appropriate beta-cell response in black South African women. Diabetes Care. 2009;32:860-5. https://doi.org/10.2337/dc08-2048.

3. Chow CC, Periwal V, Csako G, Ricks M, Courville AB, Miller BV, et al. Higher acute insulin response to glucose may determine greater free fatty acid clearance in African-American women. J Clin Endocrinol Metab. 2011;96:2456-63. https://doi.org/10.1210/jc.2011-0532.

4. Gower BA, Granger WM, Franklin F, Shewchuk RM, Goran MI. Contribution of insulin secretion and clearance to glucose-induced insulin concentration in African-American and Caucasian children. J Clin Endocrinol Metab. 2002;87:2218-24. https://doi.org/10.1210/jcem.87.5.8498.

5. Piccinini F, Polidori DC, Gower BA, Bergman RN. Hepatic but not extrahepatic insulin clearance is lower in African American than in European American women. Diabetes. 2017;66:2564-70. https://doi.org/10.2337/db17-0413.

6. Polidori DC, Bergman RN, Chung ST, Sumner AE. Hepatic and extrahepatic insulin clearance are differentially regulated: Results from a novel model-based. Diabetes. 2016;65:1556-64. https://doi.org/10.2337/db15-1373.

7. Sumner AE, Farmer NM, Cochran CS, Seeking NG, Vanevski K, Reynolds JC, et al. Obese premenopausal African-American women with normal and impaired glucose tolerance have a similar degree of insulin resistance but differ in $\beta$-cell function. Diabetes Care. 2001;24:1978-83. https://doi.org/10.2337/diacare.24.11.1978.

8. Wagenknecht LE, Langefeld CD, Scherzinger AL, Norris JM, Haffner SM, Saad MF, et al. Insulin sensitivity, insulin secretion, and abdominal fat: The Insulin Resistance Atherosclerosis Study (IRAS) Family Study. Diabetes. 2003;52:2490-6.

https://doi.org/10.2337/diabetes.52.10.2490.

9. Chandler-Laney PC, Phadke RP, Granger WM, Mũoz JA, Man CD, Cobelli C, et al. Adiposity and B-cell function: Relationships differ with ethnicity and age. Obesity. 2010;18:2086-92. https://doi.org/10.1038/oby.2010.44. 
10. Szczepaniak LS, Victor RG, Mathur R, Nelson MD, Szczepaniak EW, Tyer N, et al. Pancreatic steatosis and its relationship to $\beta$-cell dysfunction in humans: Racial and ethnic variations. Diabetes Care. 2012;35:2377-83. https://doi.org/10.2337/dc12-0701.

11. Lingvay I. Ethnic Diversity in Beta-Cell Function Susceptibility to Pancreatic Triglyceride Levels: Pilot Investigation. J Diabetes Metab 2014;05. https://doi.org/10.4172/2155-6156.1000348.

12. Goedecke JH, Keswell D, Weinreich C, Fan J, Hauksson J, Victor H, et al. Ethnic differences in hepatic and systemic insulin sensitivity and their associated determinants in obese black and white South African women. Diabetologia. 2015;58:2647-52. https://doi.org/10.1007/s00125-015-3720-7.

13. Chung ST, La Cruz MG, De, Aldana PC, Mabundo LS, DuBose CW, Onuzuruike AU, et al. Postprandial insulin response and clearance among black and white women: The federal women's study. J Clin Endocrinol Metab. 2019;104:181-92. https://doi.org/10.1210/jc.2018-01032.

14. Goedecke JH, Mendham AE, Clamp L, Nono Nankam PA, Fortuin-De Smidt MC, Phiri L, et al. An exercise intervention to unravel the mechanisms underlying insulin resistance in a cohort of black South African women: Protocol for a randomized controlled trial and baseline characteristics of participants. J Med Internet Res. 2018;20:e75. https://doi.org/10.2196/resprot.9098.

15. Goedecke JH, Micklesfield LK, Levitt NS, Lambert EV, West S, Maartens G, et al. Effect of different antiretroviral drug regimens on body fat distribution of HIV-infected South African women. AIDS Res Hum Retroviruses. 2013;29:557-63. https://doi.org/10.1089/aid.2012.0252.

16. Machann J, Bachmann OP, Brechtel K, Dahl DB, Wietek B, Klumpp B, et al. Lipid content in the musculature of the lower leg assessed by fat selective MRI: Intra- and interindividual differences and correlation with anthropometric and metabolic data. J Magn Reson Imaging. 2003;17:350-7. https://doi.org/10.1002/jmri.10255.

17. Hakim O, Bonadonna RC, Mohandas C, Billoo Z, Sunderland A, Boselli L, et al. Associations between pancreatic lipids and $\beta$-cell function in black african and white european men with type 2 diabetes. J Clin Endocrinol Metab. 2019;104:1201-10. https://doi.org/10.1210/jc.201801809.

18. Shen W, Chen J, Gantz M, Velasquez G, Punyanitya M, Heymsfield SB. A single mri slice does not accurately predict visceral and subcutaneous adipose tissue changes during weight loss. Obesity. 2012;20:2458-63. https://doi.org/10.1038/oby.2012.168.

19. Hu F, Yang R, Huang Z, Wang M, Yuan F, Xia C, et al. 3D Multi-Echo Dixon technique for simultaneous assessment of liver steatosis and iron overload in patients with chronic liver diseases: A feasibility study. Quant Imaging Med Surg. 2019;9:1014-24. https://doi.org/10.21037/qims.2019.05.20.

20. Heber SD, Hetterich H, Lorbeer R, Bayerl C, Machann J, Auweter S, et al. Pancreatic fat content by magnetic resonance imaging in subjects with prediabetes, diabetes, and controls from a general population without cardiovascular disease. PLoS One. 2017;12:1-13. https://doi.org/10.1371/journal.pone.0177154.

21. Alizai H, Nardo L, Karampinos DC, Joseph GB, Yap SP, Baum T, et al. Comparison of clinical semi-quantitative assessment of muscle fat infiltration with quantitative assessment using chemical shift-based water/fat separation in MR studies of the calf of post-menopausal women. Eur Radiol. 2012;22:1592-600. https://doi.org/10.1007/s00330-012-2404-7.

22. Bonekamp S, Ghosh P, Crawford S, Solga SF, Horska A, Brancati FL, et al. Quantitative comparison and evaluation of software packages for assessment of abdominal adipose tissue distribution by magnetic resonance imaging. Int J Obes (Lond). 2008;32:100-11. https://doi.org/10.1038/sj.ijo.0803696.

23. Bergman RN, Prager R, Volund A, Olefsky JM. Equivalence of the insulin sensitivity index in man derived by the minimal model method and the euglycemic glucose clamp. J Clin Invest. 1987;79:790-800. https://doi.org/10.1172/JCI112886.

24. Van Cauter E, Mestrez F, Sturis J, Polonsky KS. Estimation of insulin secretion rates from C-peptide levels: Comparison of individual and standard kinetic parameters for C-peptide clearance. Diabetes. 1992;41:368-77. https://doi.org/10.2337/diabetes.41.3.368.

25. Stefanovski D, Moate PJ, Boston RC. WinSAAM: A windows-based compartmental modeling system. Metabolism. 2003;52:1153-66. https://doi.org/10.1016/S0026-0495(03)00144-6.

26. Utzschneider KM, Kahn SE, Polidori DC. Hepatic insulin extraction in NAFLD is related to insulin resistance rather than liver fat content. J Clin Endocrinol Metab. 2018;104:1855-65. https://doi.org/10.1210/jc.2018-01808.

27. Jochen A, Hays J, Lee M. Kinetics of insulin internalization and processing in adipocytes: Effects of insulin concentration. J Cell Physiol. 1989;141:527-34. https://doi.org/10.1002/jcp.1041410311.

28. Eggleston EM, Jahn LA, Barrett EJ. Hyperinsulinemia rapidly increases human muscle microvascular perfusion but fails to increase muscle insulin clearance: Evidence that a saturable process mediates muscle insulin uptake. Diabetes. 2007;56:2958-63. https://doi.org/10.2337/db07-0670.

29. Jones CNO, Pei D, Staris P, Polonsky KS, Chen YDI, Reaven GM. Alterations in the Glucose-Stimulated Insulin Secretory Dose-Response Curve and in Insulin Clearance in Nondiabetic Insulin-Resistant Individuals. J Clin Endocrinol Metab. 1997;82:1834-8. https://doi.org/10.1210/jcem.82.6.3979. 
30. Goodpaster BH, Thaete FL, Simoneau JA, Kelley DE. Subcutaneous abdominal fat and thigh muscle composition predict insulin sensitivity independently of visceral fat. Diabetes. 1997;46:1579-85. https://doi.org/10.2337/diabetes.46.10.1579.

31. Tokarz VL, MacDonald PE, Klip A. The cell biology of systemic insulin function. J Cell Biol. 2018;217:1-17. https://doi.org/10.1083/jcb.201802095.

32. Le K-M, Ventura E, Fisher J, Davis J, Weigensberg M, Punyanitya M, et al. Ethnic Differences in Pancreatic Fat Accumulation and Its Relationship With Other FatDepots and Inflammatory Markers. Diabetes Care. 2011;34:485-90. https://doi.org/10.2337/dc10-0760.

33. Osei K, Schuster DP. Ethnic Differences in Secretion, Sensitivity, and Hepatic Extraction of Insulin in Black and White Americans. Diabet Med. 1994;11:755-62. https://doi.org/10.1111/j.1464-5491.1994.tb00349.x.

34. Osei K, Schuster DP, Owusu SK, Amoah AGB. Race and ethnicity determine serum insulin and C-peptide concentrations and hepatic insulin extraction and insulin clearance: Comparative studies of three populations of West African ancestry and white Americans. Metabolism. 1997;46:53-8. https://doi.org/10.1016/S0026-0495(97)90167-0.

35. Kim SP, Ellmerer M, Kirkman EL, Bergman RN. B-Cell "Rest" Accompanies Reduced First-Pass Hepatic Insulin Extraction in the InsulinResistant, Fat-Fed Canine Model. Am J Physiol - Endocrinol Metab. 2007;292:E1581-9. https://doi.org/10.1152/ajpendo.00351.2006.

36. Bergman RN, Kim SP, Catalano KJ, Hsu IR, Chiu JD, Kabir M, et al. Why visceral fat is bad: mechanisms of the metabolic syndrome. Obesity (Silver Spring). 2006;14(Suppl 1):16S-19S. https://doi.org/10.1038/oby.2006.277.

37. Hakim O, Bello O, Bonadonna RC, Mohandas C, Shojaee-Moradie F, Jackson N, et al. Ethnic differences in intrahepatic lipid and its association with hepatic insulin sensitivity and insulin clearance between men of black and white ethnicity with early type 2 diabetes. Diabetes Obes Metab. 2019;21:2163-8. https://doi.org/10.1111/dom.13771.

38. Hairston KG, Scherzinger A, Foy C, Hanley AJ, McCorkle O, Haffner S, et al. Five-year change in visceral adipose tissue quantity in a minority cohort: The insulin resistance atherosclerosis study (IRAS) family study. Diabetes Care. 2009;32:1553-5.

https://doi.org/10.2337/dc09-0336.

\section{Tables}


Table 1: Characteristics of participants by disposition index tertile

\begin{tabular}{|c|c|c|c|c|}
\hline $\mathrm{DI}_{\text {Low }}(\leq 5073.4) \mathrm{n}=15$ & $\mathrm{DI}_{\text {Intermediate }}(>5073.4-\leq 7933.2) \mathrm{n}=13$ & $\mathrm{DI}_{\text {High }}(>7933.2) \mathrm{n}=15$ & $P$ value & \\
\hline \multicolumn{5}{|l|}{ Mean $\pm S D / M e d i a n(I Q R)$} \\
\hline \multicolumn{5}{|l|}{ Age and anthropometry } \\
\hline Age (years) & $24(21-28)$ & $22(21-28)$ & $23(21-24)$ & 0.455 \\
\hline Body weight (kg) & $85.1 \pm 8.8$ & $87.8 \pm 6.3$ & $87.1 \pm 13.7$ & 0.400 \\
\hline Body mass index $\left(\mathrm{kg} / \mathrm{m}^{2}\right)$ & $33.3 \pm 2.6$ & $35.3 \pm 2.1$ & $33.6 \pm 3.5$ & 0.147 \\
\hline Waist circumference $(\mathrm{cm})$ & $103.1 \pm 5.3$ & $103.9 \pm 8.5$ & $105.8 \pm 11.0$ & 0.705 \\
\hline Waist-hip ratio & $0.89(0.84-0.95)$ & $0.89(0.87-0.91)$ & $0.90(0.85-0.94)$ & 0.899 \\
\hline \multicolumn{5}{|c|}{ Body composition and fat distribution } \\
\hline Body fat mass (\%) & $50.1 \pm 2.8$ & $51.3 \pm 3.1$ & $50.4 \pm 4.5$ & 0.660 \\
\hline Fat free soft tissue mass $(\mathrm{kg})$ & $36.9(33.8-40.3)$ & $37.4(35.8-38.8)$ & $38.7(34.9-40.6)$ & 0.791 \\
\hline Trunk fat mass (\%) & $47.9 \pm 4.7$ & $47.3 \pm 4.0$ & $46.5 \pm 4.7$ & 0.684 \\
\hline Leg fat mass (\%) & $40.0 \pm 5.2$ & $40.6 \pm 4.3$ & $40.8 \pm 5.2$ & 0.901 \\
\hline Android fat mass (\%) & $8.5 \pm 1.4$ & $8.1 \pm 0.8$ & $7.9 \pm 0.8$ & 0.284 \\
\hline Gynoid fat mass (\%) & $18.5 \pm 1.8$ & $18.7 \pm 2.0$ & $18.4 \pm 2.5$ & 0.942 \\
\hline $\operatorname{VAT}\left(\mathrm{cm}^{3}\right)$ & $1113.3 \pm 317.9$ & $931.6 \pm 355.1$ & $669.8 \pm 229.1^{\dagger}$ & 0.002 \\
\hline aSAT $\left(\mathrm{cm}^{3}\right)$ & $5303.9 \pm 1116.8$ & $5741.4 \pm 1105.2$ & $5629.1 \pm 2191.8$ & 0.747 \\
\hline VAT-aSAT & $0.20(0.16-0.24)$ & $0.15(0.11-0.21) \S$ & $0.13(0.09-0.15)^{\dagger}$ & 0.003 \\
\hline \multicolumn{5}{|l|}{ Ectopic fat } \\
\hline Mean pancreatic fat (\%) & $8.0(7.3-9.0)$ & $7.4(6.6-10.4)$ & $6.2(5.2-6.4)^{\dagger \ddagger}$ & 0.006 \\
\hline Hepatic fat (\%) & $5.6(4.5-6.1)$ & $5.9(4.5-8.4)$ & $4.5(3.9-4.9)^{\dagger \ddagger}$ & 0.023 \\
\hline Soleus fat (\%) & $10.7(10.1-11.4)$ & $9.7(8.8-11.6)$ & $9.4(6.8-10.3)$ & 0.111 \\
\hline Tibialis anterior fat (\%) & $4.1(3.3-5.7)$ & $4.2(3.5-5.4)$ & $5.0(2.6-6.1)$ & 0.953 \\
\hline SIMCL (\%) & $2.9(2.5-3.9)$ & $2.9(2.5-4.8)$ & $2.1(1.3-3.1)^{\dagger}$ & 0.055 \\
\hline SEMCL (\%) & $4.5(4.2-12.8)$ & $5.1(3.6-4.5)$ & $4.3(3.6-5.6)$ & 0.410 \\
\hline TIMCL (\%) & $0.5(0.3-0.8)$ & $0.4(0.3-0.5)$ & $0.4(0.3-0.5)$ & 0.288 \\
\hline TEMCL (\%) & $2.9(1.1-4.7)$ & $2.6(1.6-3.0)$ & $2.5(1.5-4.2)$ & 0.815 \\
\hline \multicolumn{5}{|l|}{ Fasting metabolic parameters } \\
\hline Fasting glucose (mmol/L) & $5.4 \pm 0.9$ & $5.0 \pm 0.9$ & $5.2 \pm 0.6$ & 0.411 \\
\hline Fasting insulin (pmol/L) & $85.2(63.9-119.1)$ & $82.5(78-113.7)$ & $57.7(38.6-88.5)$ & 0.107 \\
\hline Fasting C-peptide (pmol/L) & $605.7(572.6-744.8)$ & $733.2(491.5-835.8)$ & $466.7(382.3-787.8)$ & 0.218 \\
\hline C-peptide/insulin basal $_{\text {in }}$ & $6.8(6.3-8.4)$ & $8.4(6.4-9.3)$ & $9.0(7.7-10.9)$ & 0.087 \\
\hline $\mathrm{ISR}_{\text {basal }}(\mathrm{pmol} / \mathrm{min})$ & $78.7(74.4-96.8)$ & $94.7(62.9-102.4)$ & $62.4(49 .-104.6)$ & 0.567 \\
\hline HOMA2 IR\% & $2.1(1.7-2.9)$ & $2.0(1.8-2.7)$ & $1.4(1.0-2.2)$ & 0.149 \\
\hline HOMA2 B\% & $134.6(97.5-204.3)$ & $182.6(130.4-213.2)$ & $108.7(85.2-149.1)$ & 0.133 \\
\hline \multicolumn{5}{|c|}{ HbA1c and FSIGT-derived measures } \\
\hline $\mathrm{HbA} 1 \mathrm{c}$ & $5.24 \pm 0.36$ & $5.19 \pm 0.36$ & $5.20 \pm 0.43$ & 0.829 \\
\hline Disposition index $(\mathrm{AU}) \times 10^{3}$ & $3780(2989-4527)$ & $6596(6070-7119) \S$ & $9995(9247-13882){ }^{\dagger \ddagger}$ & $<0.001$ \\
\hline
\end{tabular}




\begin{tabular}{|c|c|c|c|c|}
\hline $\mathrm{S}_{\mathrm{I}}(\mathrm{mU} / \mathrm{I})^{-1} \mathrm{~min}^{-1}$ & $1.94(1.1-2.8)$ & $1.97(1.4-3.1)$ & $3.1(2.2-4.5)^{\dagger \ddagger}$ & 0.008 \\
\hline $\mathrm{AIR}_{\mathrm{g}} \mathrm{mU} \mathrm{l}^{-1} \mathrm{~min}^{-1}$ & 2159 (1465-3159) & 2909 (2544-4870) & 3561 (4278-4514) & 0.064 \\
\hline $\operatorname{Sg}\left(\min ^{-1}\right)$ & $0.017 \pm 0.008$ & $0.024 \pm 0.008$ & $0.031 \pm 0.008^{\dagger}$ & $<0.001$ \\
\hline $\mathrm{ISR}_{\text {first phase }}(\mathrm{pmol} / \mathrm{min})$ & $2692(1909-4023)$ & 3624 (2826-4999) & 4049 (2758-4877) & 0.060 \\
\hline $\mathrm{ISR}_{\text {total }}(\mathrm{pmol} / \mathrm{min})$ & $4246(3231-8095)$ & 5589 (4813-7913) & $4272(3261-6500)$ & 0.365 \\
\hline $\mathrm{FE}_{\mathrm{L}}(\%)$ & $61.6 \pm 11.9$ & $54.5 \pm 8.7$ & $51.4 \pm 9.4^{\dagger}$ & 0.042 \\
\hline CLp (ml/min/kg) & 74.7 (61.3-105.3) & 91.5 (77.1-125.8) & $128.9(92.3-168.2)^{\dagger}$ & 0.009 \\
\hline
\end{tabular}

Mean ( $\pm S D$ ) for normally distributed variables and median (IQR) for non-normally distributed variables; DI - Disposition index, VAT - visceral adipose tissue, aSAT - abdominal subcutaneous adipose tissue, SIMCL-soleus intra-myocellular fat, SEMCL - Tsoleus extra-myocellular fat, TIMCL - tibialis anterior intra-myocellular fat, TEMCL - tibialis anterior extra-myocellular fat, ISR - insulin secretion rate, HOMA - homeostatic model assessment 2 of insulin resistance (IR) and beta cell function (B), SI - insulin sensitivity, AIRg - acute insulin response to glucose, Sg glucose effectiveness, $F E_{L}$ - fractional hepatic insulin extraction; CL $p$ - peripheral insulin clearance. P value derived from ANOVA or Kruskal Wallis, significant post-hoc differences. ${ }^{+}$High DI compared to low DI; ${ }^{\ddagger}$ High DI compared to intermediate DI; $§$ Intermediate DI compared to low DI with $P \leq 0.05$ deemed as statistically significant.

Table 2: Relationship of $\beta$-cell function and insulin sensitivity with hepatic and peripheral insulin clearance

\begin{tabular}{|c|c|c|c|c|c|c|c|c|c|c|}
\hline \multirow[t]{2}{*}{ Model } & \multirow[t]{2}{*}{ Variables } & \multicolumn{2}{|l|}{ Sqrt DI } & \multicolumn{3}{|l|}{$\ln \mathrm{AIR}_{\mathrm{g}}$} & \multicolumn{2}{|l|}{ In ISR first phase } & \multicolumn{2}{|l|}{$\ln S_{I}$} \\
\hline & & $\begin{array}{l}\beta(P \\
\text { value })\end{array}$ & $\mathrm{R}^{2}$ & $\beta$ ( $P$ value) & $\mathrm{R}^{2}$ & & $\beta$ (P value) & $\mathrm{R}^{2}$ & $\begin{array}{l}\beta(P \\
\text { value })\end{array}$ & $\mathrm{R}^{2}$ \\
\hline 1. & $\mathrm{FE}_{\mathrm{L}}(\%)$ & $\begin{array}{l}-0.709 \\
(0.010)\end{array}$ & 0.168 & $\begin{array}{l}-0.016 \\
(<0.001)\end{array}$ & & 0.576 & $\begin{array}{l}-0.011 \\
(<0.001)\end{array}$ & 0.403 & $\begin{array}{l}0.008 \\
(0.065)\end{array}$ & 0.089 \\
\hline 2. & $\begin{array}{l}\text { In CLp } \\
(\mathrm{ml} / \mathrm{min} / \mathrm{kg})\end{array}$ & $\begin{array}{l}55.80 \\
(0.002)\end{array}$ & 0.234 & $0.623(0.0$ & 04) & 0.204 & $\begin{array}{l}0.644 \\
(<0.001)\end{array}$ & 0.293 & $\begin{array}{l}-0.042 \\
(0.881)\end{array}$ & 0.001 \\
\hline 3. & $\mathrm{FE}_{\mathrm{L}}(\%)$ & $\begin{array}{l}-0.364 \\
(0.222)\end{array}$ & 0.265 & $\begin{array}{l}-0.015 \\
(<0.001)\end{array}$ & & 0.579 & $\begin{array}{l}-0.009 \\
(0.002)\end{array}$ & 0.430 & $\begin{array}{l}0.010 \\
(0.038)\end{array}$ & 0.115 \\
\hline \multicolumn{2}{|c|}{ In CLp (ml/min/kg) } & $\begin{array}{l}42.78 \\
(0.035)\end{array}$ & $\begin{array}{l}0.086 \\
(0.630)\end{array}$ & $0.335(0.060)$ & \multicolumn{2}{|c|}{$\begin{array}{l}0.320 \\
(0.313)\end{array}$} & & & & \\
\hline 4. & $\mathrm{FE}_{\mathrm{L}}(\%)$ & - & $\begin{array}{l}-0.011 \\
(<0.001)\end{array}$ & 0.765 & & $\begin{array}{l}-0.005 \\
(0.023)\end{array}$ & 0.647 & - & & \\
\hline \multicolumn{2}{|c|}{ In CLp (ml/min/kg) } & - & $0.206(0.138)$ & $0.438(0.004)$ & - & & & & & \\
\hline \multicolumn{2}{|c|}{$\ln \mathrm{S}_{\mathrm{I}}\left((\mathrm{mU} / \mathrm{I})^{-1} \mathrm{~min}^{-1}\right)$} & - & $\begin{array}{l}-0.374 \\
(<0.001)\end{array}$ & $\begin{array}{l}-0.324 \\
(<0.001)\end{array}$ & - & & & & & \\
\hline
\end{tabular}

$\beta$ - linear regression coefficient, Sqrt- square root, $L n$ - natural log,DI - disposition index, $S_{\text {I }}$ - insulin sensitivity, AlRg - acute insulin response to glucose, ISR-insulin secretion rate, $F E_{L}$ - fractional hepatic insulin extraction, CL $p$ - peripheral insulin clearance; $p \leq 0.05$ regarded as statistically significant 
Table 3: The contribution of first phase insulin secretion and hepatic insulin extraction to acute insulin response to glucose

\begin{tabular}{|c|c|c|c|c|c|}
\hline \multirow[t]{2}{*}{ Model } & \multirow[t]{2}{*}{ Variables } & \multirow{2}{*}{$\begin{array}{l}\text { Ln AlR } \\
\text { } \beta \text {-coefficient } \pm \text { SE }\end{array}$} & \multirow[b]{2}{*}{ Partial beta } & \multirow[b]{2}{*}{$\mathbf{P}$} & \multirow[b]{2}{*}{ Model $\mathrm{R}^{2}$} \\
\hline & & & & & \\
\hline 1. & In ISR first phase & $0.99 \pm 0.07$ & - & $<0.001$ & 0.819 \\
\hline 2. & Hepatic insulin extraction (\%) & $-0.016 \pm 0.002$ & - & $<0.001$ & 0.576 \\
\hline 3. & In ISR first phase & $0.813 \pm 0.091$ & 0.701 & $<0.001$ & 0.869 \\
\hline Hepatic insulin extraction (\%) & $-0.007 \pm 0.002$ & -0.314 & 0.001 & & \\
\hline 4. & In ISR first phase & $0.667 \pm 0.094$ & 0.574 & $<0.001$ & 0.898 \\
\hline Hepatic insulin extraction (\%) & $-0.007 \pm 0.001$ & -0.333 & $<0.001$ & & \\
\hline $\ln S_{1}$ & $-0.166 \pm 0.053$ & -0.203 & 0.004 & & \\
\hline
\end{tabular}

Ln - natural log, AIRg - acute insulin response to glucose, SE - Standard error, ISR - insulin secretion rate, $S_{\text {I }}$ insulin sensitivity

Table 4: Correlations of components of disposition index, insulin sensitivity, secretion and clearance, with central adipose tissue depots

\begin{tabular}{|c|c|c|c|c|c|c|c|}
\hline \multicolumn{2}{|c|}{$\begin{array}{l}\text { Model } 1 \\
\beta \text {-coefficient ( } p \text { value) }\end{array}$} & & \multicolumn{3}{|c|}{$\begin{array}{l}\text { Model } 2 \\
\beta \text {-coefficient ( } p \text { value) }\end{array}$} & \multirow[b]{2}{*}{$\begin{array}{l}\mathrm{FE}_{\mathrm{L}} \\
(\%)\end{array}$} & \\
\hline $\begin{array}{l}\ln S_{\mid} \\
(m U / I)^{-1} \mathrm{~min}^{-}\end{array}$ & $\begin{array}{l}\text { In } \text { AIR }_{\mathrm{g}} \\
\mathrm{mU} \mathrm{l}^{-1} \mathrm{~min}^{-1}\end{array}$ & $\begin{array}{l}\text { In ISR } \text { first phase } \\
\text { (pmol/min) }\end{array}$ & $\begin{array}{r}\mathrm{FE}_{\mathrm{L}} \\
(\%)\end{array}$ & $\begin{array}{l}\text { In AIR } \\
\mathrm{mU} \mathrm{I}^{-1} \\
\mathrm{~min}^{-1}\end{array}$ & $\begin{array}{l}\text { In ISR } \text { first phase } \\
\text { (pmol/min) }\end{array}$ & & \\
\hline VAT $\mathrm{cm}^{3}$ & $\begin{array}{l}-3.07 \times 10^{-4} \\
(0.011)\end{array}$ & $-0.74 \times 10^{-4}(0.511)$ & $\begin{array}{l}-0.43 \times 10^{-4} \\
(0.667)\end{array}$ & $\begin{array}{l}0.008 \\
(0.101)\end{array}$ & $-2.780 \times 10^{-4}(0.006)$ & $\begin{array}{l}-2.02 \times 10^{-4} \\
(0.033)\end{array}$ & $\begin{array}{l}0.013 \\
(0.012)\end{array}$ \\
\hline aSAT $\mathrm{cm}^{3}$ & $\begin{array}{l}-0.33 \times 10^{-4} \\
(0.248)\end{array}$ & $0.50 \times 10^{-4}(0.049)$ & $\begin{array}{l}0.21 \times 10^{-4} \\
(0.365)\end{array}$ & $\begin{array}{l}-0.001 \\
(0.507)\end{array}$ & $0.34 \times 10^{-4}(0.114)$ & $\begin{array}{l}-0.01 \times 10^{-4} \\
(0.957)\end{array}$ & $\begin{array}{l}-0.0003 \\
(0.823)\end{array}$ \\
\hline $\begin{array}{l}\text { In VAT-aSAT } \\
\text { ratio }\end{array}$ & $\begin{array}{l}-0.320 \\
(0.179)\end{array}$ & $\begin{array}{l}-0.427 \\
(0.042)\end{array}$ & $\begin{array}{l}-0.220 \\
(0.253)\end{array}$ & $\begin{array}{l}23.9 \\
(0.016)\end{array}$ & $\begin{array}{l}-0.617 \\
(<0.001)\end{array}$ & $\begin{array}{l}-0.327 \\
(0.054)\end{array}$ & $\begin{array}{l}27.16 \\
(0.006)\end{array}$ \\
\hline
\end{tabular}

Unadjusted (Model 1) and adjusted for $S_{I}$ (Model 2). $S_{I}$ - Insulin sensitivity, AIRg - acute insulin response to glucose, ISR-insulin secretion rate, $F E_{L}$ - hepatic insulin extraction, VAT - visceral adipose tissue, SAT - abdominal subcutaneous adipose tissue. Ln - natural log transformed variable 
Table 5: Correlation matrix between regional and ectopic fat depots

\begin{tabular}{|c|c|c|c|c|c|c|c|c|}
\hline \multicolumn{2}{|l|}{$\operatorname{VAT}\left(\mathrm{cm}^{3}\right)$} & SAT $\left(\mathrm{cm}^{3}\right)$ & $\begin{array}{l}\text { Pancreatic fat } \\
(\%)\end{array}$ & $\begin{array}{l}\text { Hepatic fat } \\
(\%)\end{array}$ & $\begin{array}{l}\text { Soleus fat } \\
(\%)\end{array}$ & $\begin{array}{l}\text { Tibialis anterior } \\
\text { fat (\%) }\end{array}$ & $\begin{array}{l}\text { SIMCL } \\
(\%)\end{array}$ & $\begin{array}{l}\text { SEMCL } \\
(\%)\end{array}$ \\
\hline VAT $\left(\mathrm{cm}^{3}\right)$ & 1 & \multirow[b]{2}{*}{1} & \multirow[b]{3}{*}{1} & \multirow{5}{*}{1} & & & & \\
\hline SAT $\left(\mathrm{cm}^{3}\right)$ & $\begin{array}{l}0.338 \\
(0.029)\end{array}$ & & & & & & & \\
\hline Pancreatic fat (\%) & $\begin{array}{l}0.417 \\
(0.007)\end{array}$ & $\begin{array}{l}-0.070 \\
(0.662)\end{array}$ & & & & & & \\
\hline \multirow[t]{2}{*}{ Hepatic fat (\%) } & \multirow{2}{*}{$\begin{array}{l}0.300 \\
(0.060)\end{array}$} & 0.323 & \multirow{2}{*}{$\begin{array}{l}0.540 \\
(<0.001)\end{array}$} & & \multirow{4}{*}{1} & & & \\
\hline & & $(0.042)$ & & & & & & \\
\hline \multirow[t]{2}{*}{ Soleus fat (\%) } & \multirow{2}{*}{$\begin{array}{l}0.128 \\
(0.438)\end{array}$} & \multirow{2}{*}{$\begin{array}{l}-0.349 \\
(0.029)\end{array}$} & 0.329 & 0.048 & & \multirow{4}{*}{1} & & \\
\hline & & & $(0.044)$ & $(0.779)$ & & & & \\
\hline \multirow{2}{*}{$\begin{array}{l}\text { Tibialis anterior } \\
\text { fat (\%) }\end{array}$} & \multirow{2}{*}{$\begin{array}{l}-0.015 \\
(0.926\end{array}$} & \multirow{2}{*}{$\begin{array}{l}-0.201 \\
(0.220)\end{array}$} & 0.266 & 0.022 & \multirow{2}{*}{$\begin{array}{l}0.503 \\
(<0.001)\end{array}$} & & \multirow{4}{*}{1} & \\
\hline & & & $(0.107)$ & $(0.898)$ & & & & \\
\hline \multirow[t]{2}{*}{ SIMCL (\%) } & \multirow{2}{*}{$\begin{array}{l}0.403 \\
(0.014)\end{array}$} & \multirow{2}{*}{$\begin{array}{l}-0.044 \\
(0.796)\end{array}$} & 0.395 & 0.093 & \multirow{2}{*}{$\begin{array}{l}0.585 \\
(<0.001)\end{array}$} & 0.547 & & \multirow{4}{*}{1} \\
\hline & & & $(0.017)$ & $(0.595)$ & & $(<0.001)$ & & \\
\hline \multirow[t]{2}{*}{ SEMCL (\%) } & \multirow{2}{*}{$\begin{array}{l}0.121 \\
(0.474)\end{array}$} & \multirow{2}{*}{$\begin{array}{l}-0.004 \\
(0.981)\end{array}$} & 0.087 & \multirow{2}{*}{$\begin{array}{l}-0.127 \\
(0.468)\end{array}$} & 0.426 & 0.392 & 0.234 & \\
\hline & & & $(0.613)$ & & $(0.009)$ & $(0.017)$ & $(0.153)$ & \\
\hline \multirow[t]{2}{*}{ Leg fat mass (\%) } & \multirow{2}{*}{$\begin{array}{l}-0.450 \\
(0.003)\end{array}$} & \multirow{2}{*}{$\begin{array}{l}-0.623 \\
(<0.001)\end{array}$} & \multirow[t]{2}{*}{$-0.038(0.812)$} & \multirow{2}{*}{$\begin{array}{l}-0.293 \\
(0.067)\end{array}$} & 0.334 & 0.107 & 0.024 & 0.125 \\
\hline & & & & & $(0.033)$ & $(0.504)$ & $(0.885)$ & $(0.448)$ \\
\hline
\end{tabular}

VAT - Visceral adipose tissue, SAT - abdominal subcutaneous adipose tissue, SIMCL - soleus intra-myocellular fat, SEMCL - soleus extramyocellular fat, Data expressed as correlation coefficient ( $P$ value). $P \leq 0.05$ is deemed statistically significant

\section{Figures}

A

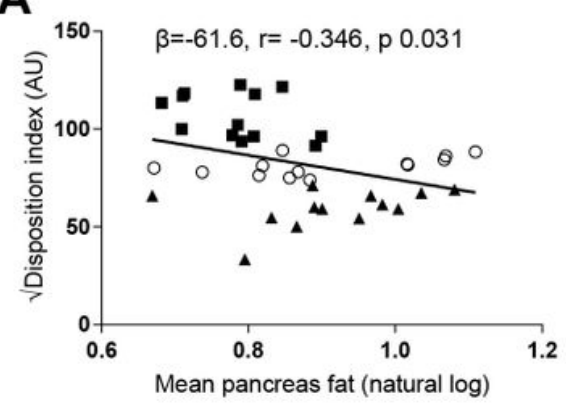

D

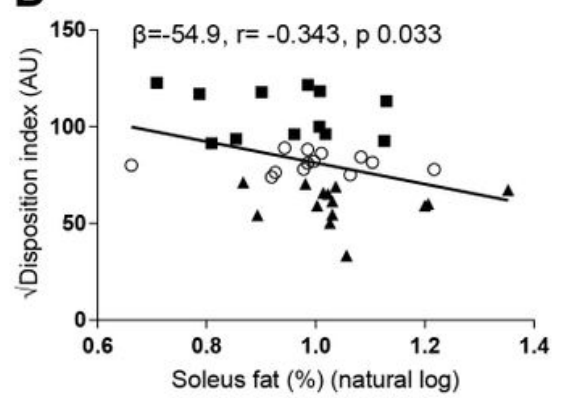

B

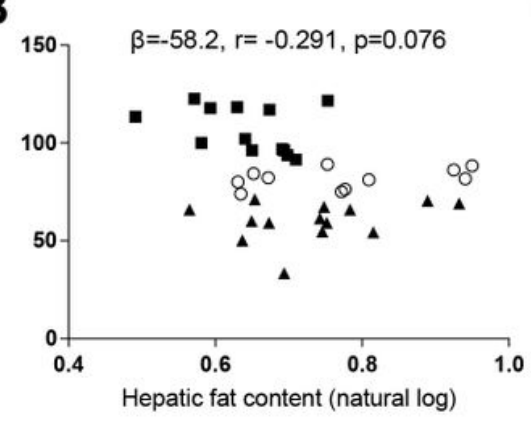

E

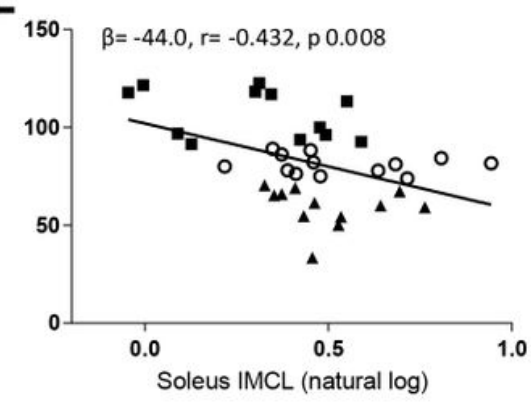

C

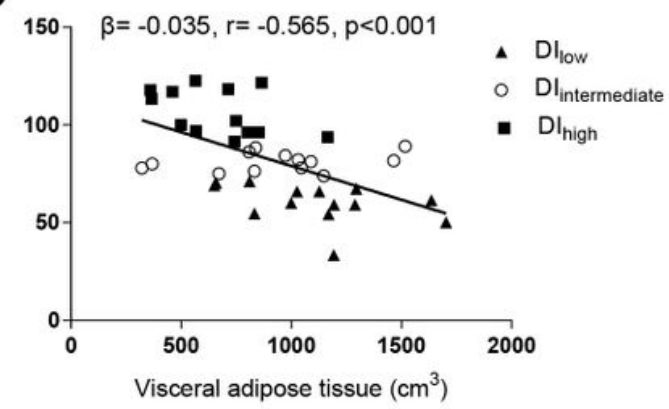

F

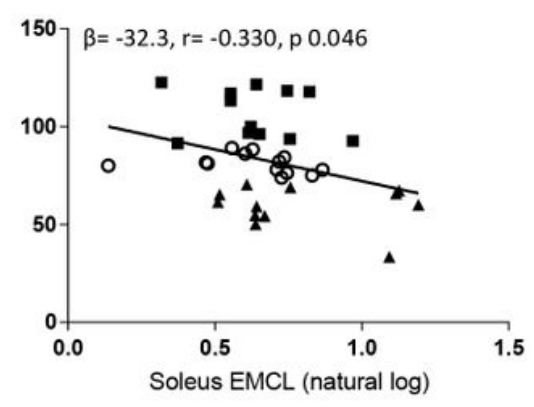

Figure 1 
Disposition index (DI) associations: with (A) pancreatic fat (B) hepatic fat, (C) visceral adipose tissue, (D) soleus fat (E) soleus intra-myocellar fat (IMCL) and (F) soleus extra-myocellular fat (EMCL) in those with low DI (solid black triangles), intermediate DI (open circles) and high DI (solid black square). Regression line indicates significant association $(p<0.05)$ in the whole cohort, $\beta$ (slope), $r$ - correlation coefficients 